\title{
Association of HPV genotypes with external anogenital warts: a cross sectional study
}

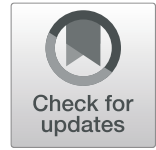

Rana Al-Awadhi ${ }^{1 *}$ D, Nawaf Al-Mutairi' ${ }^{2}$ Ahmed N. Albatineh ${ }^{3}$ and Wassim Chehadeh ${ }^{4}$

\begin{abstract}
Background: This study was undertaken to determine the distribution of type-specific human papillomavirus (HPV) in external anogenital warts, and the correlation with clinical presentation of warts and demographic data of patients.

Methods: Genital warts specimens were obtained from 129 men and 27 women attending a dermatology clinic, who had been advised surgical excision. The tissues were fixed and screened for HPV DNA by using real-time PCR. HPV genotype was determined by PCR-based sequencing.

Results: Sixteen different HPV genotypes were detected, comprising 4 oncogenic HPV genotypes $(16,18,33,38), 2$ low-risk HPV types (LR) (6, 81), HPV 9, and other types associated with common warts (1a, 2, 4, 7, 27b, 27, 57b, 57c, 65). Oncogenic HPV types were found in $34.62 \%$ of patients, LR HPV types in $14.4 \%$, HPV 9 in $0.64 \%$, and common warts type in 50.6\%. The prevalence of HPV infection with a single type was $88.4,9.0 \%$ for two types, and $2.6 \%$ for three types. Multiple logistic regression model showed that age, gender, nationality, number of warts, size of each wart, and positive history of wart in sexual partner, were not predictors of HPV type. However, patients with anogenital warts of one to six months duration were three times more likely to have oncogenic HPV infection compared to those with less than one month.
\end{abstract}

Conclusions: This study shows that oncogenic HPV types are detected in around 35\% of patients with genital warts, and are prevalent in warts of one to six months duration.

Keywords: Anogenital warts, HPV, Prevalence, Multiple regression

\section{Background}

Anogenital condyloma acuminata are warts around the genital and anal areas. More than $90 \%$ of anogenital warts are caused by HPV type 6 and $11[13,28]$. In women, external anogenital warts are always accompanied by flat or exophytic warts of the vagina and cervix [26]. In men, genital HPV infection is manifested by the presence of condyloma acuminata of anogenital areas, penile intraepithelial neoplasia and penile carcinoma [23]. Since HPV is a sexually transmitted virus, the incidence of external anogenital warts is also associated with the sexual behavior of patients $[14,26]$.

Limited reports are available on HPV infection and anogenital warts locally and worldwide. In the Kuwaiti context,' one report published in 2004 by Al-Fouzan and Al-Mutairi [3] presented an overview of the incidence of

\footnotetext{
* Correspondence: r.al-awadhi@hsc.edu.kw

${ }^{1}$ Department of Medical Laboratory Sciences, Faculty of Allied Health Sciences, Kuwait University, P.O. Box 31470, 90805 Sulaibikhat, Kuwait Full list of author information is available at the end of the article
}

sexually transmitted infections (STI) in Kuwait. They found that the incidence of genital warts (condyloma accuminata) has shown steady increase from $2.04 \%$ of STI cases in 1998 to $2.3 \%$ in 2002 . The results were based on clinical diagnosis. Another report was carried out in 2007 by Al-Mutairi et al. [4] to determine the clinical patterns, sociodemographic factors, and sexual practices of patients with STI who attended a government hospital in Kuwait found that $13.7 \%$ of 1096 patients included in the study had genital warts.

We have previously conducted a study to determine the prevalence and type specific distribution of HPV in women with normal cervical cytology samples in Kuwait. HPV DNA was detected in $2.4 \%$ of women with cytologically normal cervices; low-risk (LR) HPV types were detected in $71.8 \%$ of the infected samples, high-risk (HR) HPV types in $32.3 \%$, and intermediate-risk (IR) types in $7 \%$ [2]. We have also reported the presence of HPV DNA in $51 \%$ of abnormal cervical cytology samples; HPV16 had

(c) The Author(s). 2019 Open Access This article is distributed under the terms of the Creative Commons Attribution 4.0 International License (http://creativecommons.org/licenses/by/4.0/), which permits unrestricted use, distribution, and 
the highest prevalence (24.3\%), followed by HPV11 (13.8\%), HPV66 (11.2\%) and HPV33 (9.9\%), [1].

Three different prophylactic HPV vaccines are currently approved. Gardasil/Silgard which targets HPV6, 11, 16, and 18; Cervarix which targets HPV 16 and 18; and Gardasil 9 which targets HPV6, 11, 16, 18, 31, 33, 45, 52, and 58, reviewed in Gupta et al., 2018 [17].

In order to investigate whether the HPV types associated with genital warts are covered by the current licensed HPV vaccines, the HPV types detected in the genital warts were identified by direct sequencing. Demographic data and warts characteristics were used in a regression model to predict the HPV type.

\section{Methods}

\section{Study design and participants}

A cross sectional study that uses a non-probabilistic sample was conducted. Patients attending dermatology clinics at Farwania Health District Area were recruited in the study consecutively from November 2016 to May 2017. Immunocompetent patients with previous clinical diagnosis of external anogenital warts scheduled for cryotherapy or laser treatment were asked to sign the consent form after a verbal explanation from the dermatologist soliciting their participation. At the time of sampling, wart specimens were collected in universal transporting medium (HealthLink Inc., Copan Italia S.p.A., Italy), and stored at $-80^{\circ} \mathrm{C}$. Ethical approval was obtained from the Health Sciences Center Ethical Committee (Number: VDR/EC/2310) and Ministry of Health.

Demographic and clinical information were taken from each patient, including: age (years), gender (male, female), nationality (Kuwaiti, non-Kuwaiti), number of warts (one, two to four, and at least five), duration of the presence of warts $(<$ one month, one to six months, seven to 12 months, and more than 12 months), size of each wart (in centimeter) $(<$ one, one, between one and two, more than two), partners has warts (yes, no), and if warts were subject to prior treatment (yes, no). None of the participants received HPV vaccination, because HPV vaccination has not yet been implemented in Kuwait, although its implementation is currently being discussed at the Ministry of Health.

\section{DNA extraction and controls}

Received tissue samples were stored at $-80^{\circ} \mathrm{C}$. Due to the large number of samples received, all warts per patient were minced together and were subjected to one DNA isolation. Tissue was minced with sterile scissor and forceps on a Petri dish and about 25-mg of tissue was weighed. The tissue was washed in phosphate buffered saline (PBS) and transferred into 1.5-ml Eppendorf tubes. Genomic DNA was extracted from tissue samples using a QIAmp DNA Mini kit (Qiagen, USA) according to the manufacturer's instructions.
HPV type 2, HPV type 1 and HPV type 16 vectors (American Type Culture Collection, Manassas, VA, USA) were used as controls in PCR experiments.

\section{Real time PCR}

The real-time PCR assay was carried out to screen for HPV DNA in the genital warts. Five microlitres $(5-\mu \mathrm{l})$ of the extracted DNA was combined with $12.5-\mu \mathrm{l}$ of $2 \mathrm{X}$ Syber Green master mix (Applied Biosystems, Foster City, CA, USA) containing ROX as a passive reference, and $10 \mathrm{pmol}$ of forward and reverse primers $(10-\mathrm{uM}$, described below). All sets of the primers were custom synthesised by Thermo Fisher Scientific, Waltham, Massachusetts, USA. The mixture was made up to 25- $\mu$ l volume with nuclease free water (Ambion, Austin, TX, USA). In order to reduce the number of false positive or negative results, samples were analyzed in duplicate on a 96 optical well reaction plate (Applied Biosystems, Foster City, CA, USA). Positive and negative controls were included in each amplification batch. In order to quantify the HPV in the samples, a five to 10 fold serial dilution of the known positive control DNA was performed alongside the samples. Real-time PCR amplification was carried out in ABI 7500 real-time PCR (Applied Biosystems, Foster City, CA, USA).

The real-time PCR assay was carried out on three different plates. The first plate was used to determine the integrity of the target DNA by $\beta$-globin PCR assay, amplifying a target of 268-bp fragment, as described previously by Lum and Le Marchand in 1998 [20]. The nucleotide sequence of $\beta$-globin primers is as follows: $\beta$-globin forward PCR primer: 5'-TGGGTTTCTGATAGGCACTGACT-3'. $\beta$-globin reverse PCR primer: $5^{\prime}$-AACAGCATCAGGAGTGGACAGAT-3'.The PCR amplification was initiated at $95^{\circ} \mathrm{C}$ for ten minutes and completed by 45 amplification cycles (denaturation at $95^{\circ} \mathrm{C}$ for $15 \mathrm{~s}$, annealing at $55^{\circ} \mathrm{C}$ for $45 \mathrm{~s}$ and extension at $65^{\circ} \mathrm{C}$ for one minute).

The second plate was used to screen for the presence of HPV infection using MY11/GP6 primers from the HPV L1 ORF [6]. The nucleotide sequences of MY11/GP6 primers [6] are as follows: MY11 forward primer: 5'GCM CAG GGW CAC AAY AAT GG $-3^{\prime}$ and GP6 reverse primer: $5^{\prime}$ - GAAAAATAAACTGTAAATCATAT TC- $3^{\prime}$. The expected size of amplified fragment is $185-\mathrm{bp}$. The PCR amplification was initiated at $95^{\circ} \mathrm{C}$ for ten minutes and completed by 45 amplification cycles (denaturation at $95^{\circ} \mathrm{C}$ for $15 \mathrm{~s}$, annealing at $45^{\circ} \mathrm{C}$ for $45 \mathrm{~s}$ and extension at $65^{\circ} \mathrm{C}$ for one minute).

The third plate was used to screen for the presence of HPV infection using HVP2/B5 primers from the HPV L1 ORF [18]. The nucleotide sequences of HVP2/B5 primers are as follows: HVP2 forward primer: $5^{\prime}-\mathrm{TCN}$ MGN GGN CAN CCN YTN GG -3'; B5 reverse primer: 
5'- AYN CCR TTR TTR TGN CCY TG -3'. The expected size of the amplified fragment is 650-bp. The PCR amplification was initiated at $95^{\circ} \mathrm{C}$ for ten minutes and completed by 45 amplification cycles (denaturation at $95^{\circ} \mathrm{C}$ for $15 \mathrm{~s}$, annealing at $50^{\circ} \mathrm{C}$ for $45 \mathrm{~s}$ and extension at $65{ }^{\circ} \mathrm{C}$ for one minute).

Fluorescence spectra were recorded during the elongation phase of each PCR cycle. Sequence Detection Software (SDS v1.7) of ABI 7500 real-time PCR was used to generate the amplification curve for each reaction. A dissociation curve was generated after each reaction to differentiate between specific and non-specific amplicons. On the basis of the amplification curve, all samples with HPV amplification starting at any cycle and up to cycle number 40 (with a cut-off line of 0.2 ) were selected for the analysis. Only samples with a dissociation curve between $70{ }^{\circ} \mathrm{C}$ and $80^{\circ} \mathrm{C}$ and with a derivative value between $0.100-0.500$ were considered HPV DNA positive.

\section{Sanger sequencing}

Samples showing positive amplification for the presence of HPV by MY11/GP6 were subjected to conventional PCR assay. The expected HPV genotype spectrum to be detected from mucosal warts using MY11/GP6 includes, HR HPV genotypes: 9, 16, 18, 26, 31, 33, 35, 38, 39, 45, $51,52,55,56,58,59$ and 68 , LR HPV genotypes: 6, 11, $40,42,53,54,57,66$ and 81 [16].

HPV DNA in warts was amplified by nested PCR prior to sequencing, using the AmpliTaq Gold Master Mix (Applied Biosystems, Foster City, CA, USA) HVP2/B5 primers were used in the first PCR, and CN1F/CN1R, $\mathrm{CN} 2 \mathrm{~F} / \mathrm{CN} 2 \mathrm{R}, \mathrm{CN} 3 \mathrm{~F} / \mathrm{CN} 3 \mathrm{R}$ and $\mathrm{C} 4 \mathrm{~F} / \mathrm{C} 4 \mathrm{R}$ primers [18] in the second PCR. The first PCR amplification was initiated at $95^{\circ} \mathrm{C}$ for ten minutes and completed by 35 amplification cycles (denaturation at $95^{\circ} \mathrm{C}$ for $15 \mathrm{~s}$, annealing at $50^{\circ} \mathrm{C}$ for $45 \mathrm{~s}$ and extension at $68^{\circ} \mathrm{C}$ for one minute). The second PCR amplification was carried out using $3 \mu \mathrm{l}$ of the first PCR product, and the same cycling conditions. The expected broad-spectrum HPV genotypes to be detected from cutaneous warts using HVP2/B5 and CN1F/CN1R, CN2F/CN2R, CN3F/CN3R and $\mathrm{C} 4 \mathrm{~F} / \mathrm{C} 4 \mathrm{R}$ primers includes HPV types from genera alpha (HPV 2, 3, 7, 10, 27, 28, 29, 40, 43, 57, 77, 91 and 94), gamma (HPV 4, 65, 95, 48, 50, 60 and 88), mu (HPV 1 and 63), and nu (HPV 41) [12].

The PCR products were purified using a PCR purification kit (NucleoSpin Extract II PCR Purification Kit, Macherey-Nagel GmbH \& Co.KG, Düren, Germany) as per the manufacturer's instructions. They were then subjected to Sanger sequencing reaction using BigDye terminator v3.1 cycle sequencing mix (Applied Biosystems, Foster City, CA, USA), and the nested PCR primers described above. Post sequencing PCR purifications were performed to remove unbound fluorescent dye deoxy terminators using BigDye XTerminator ${ }^{\mathrm{Tm}}$ Purification kit (Applied Biosystems, Foster City, CA, USA). The samples were denatured for $2 \mathrm{~min}$ at $95^{\circ} \mathrm{C}$ and immediately chilled on ice and loaded on an ABI 3100 Genetic Analyzer (Applied Biosystems, Foster City, CA, USA). Samples were electrophoresed on a 50-cm capillary array using POP 6 polymer (Applied Biosystems, Foster City, CA, USA) as a separation medium.

The samples were analyzed using Sequencing Analysis software v 3.7 (Applied Biosystems, Foster City, CA, USA). The HPV sequence alignment was performed with sequences presented in the GenBank database using BLASTn software (https://blast.ncbi.nlm.nih.gov/) and the Los Alamos Data National Laboratory Theoretical Biology and Biophysics HPV database (https://pave. niaid.nih.gov/).

When obtained sequences were of poor quality due to low yield of PCR product, the PCR products were cloned into the pGEM-T Easy Vector (Promega, Madison, WI)

Table 1 Clinical and demographic characteristics of patients with anogenital warts $(N=156)$

\begin{tabular}{|c|c|}
\hline Characteristic & $n(\%)$ \\
\hline \multicolumn{2}{|l|}{ Gender } \\
\hline Male & $129(82.7)$ \\
\hline Female & $27(17.3)$ \\
\hline \multicolumn{2}{|l|}{ Nationality } \\
\hline Kuwaiti & $79(50.6)$ \\
\hline Non-Kuwaiti & $77(49.4)$ \\
\hline \multicolumn{2}{|l|}{ Number of Warts } \\
\hline One & $3(1.9)$ \\
\hline Two - Four & $89(57.1)$ \\
\hline At least Five & $64(41.0)$ \\
\hline \multicolumn{2}{|c|}{ Duration of presence of each Wart } \\
\hline Less than one month & $33(21.2)$ \\
\hline One - six months & $80(51.3)$ \\
\hline Seven - Twelve months & $29(18.6)$ \\
\hline More than 12 months & $14(9.0)$ \\
\hline \multicolumn{2}{|l|}{ Size of each Wart } \\
\hline Less than one $\mathrm{Cm}^{1}$ & $36(23.1)$ \\
\hline One $\mathrm{Cm}$ & $37(23.7)$ \\
\hline One - two Cm & $70(44.9)$ \\
\hline More than two $\mathrm{Cm}$ & $13(8.3)$ \\
\hline \multicolumn{2}{|c|}{ Wart subject to prior treatment } \\
\hline No & $91(58.3)$ \\
\hline Yes & $65(41.7)$ \\
\hline \multicolumn{2}{|l|}{ Partner has Warts } \\
\hline No & $118(75.6)$ \\
\hline Yes & $38(24.4)$ \\
\hline
\end{tabular}

Data are numbers of patients (\%). ${ }^{1:}$ Centimeter 
following purification with the Wizard SV Gel and PCR Clean-Up System kit (Promega), and the sequencing of inserts was performed using M13 forward and reverse primers.

\section{Statistical analysis}

Data of the clinical diagnosis, demographic data and virological analysis were tabulated and analyzed using SPSS statistical software 'Statistical Package for Social Sciences, SPSS version 25.0' (IBM Corp, Armonk, NY, USA). Descriptive statistics: frequencies/percentages, measures of center and dispersion were calculated. For testing equality of means, the two-sample t-test was used for all continuous variables when normality was held, otherwise Mann Whitney U test was used. For comparing means of three groups, either analysis of variance or Kruskal-Wallis test was used depending on the assumptions being satisfied. Pearson chi square test for independence or Fisher exact test were used to test associations between two categorical variables when the assumptions were satisfied. To model a binary outcome with a set of covariates, logistic regression was implemented, and crude and adjusted odds ratios and their 95\% confidence intervals were estimated. All tests were two tailed and a $P$ value less than $5 \%$ was considered statistically significant.

\section{Results}

External anogenital wart samples obtained from 156 patients attending outpatient dermatology clinics were

Table 2 HPV type-specific prevalence in patients with anogenital warts $(N=156)$

\begin{tabular}{|c|c|c|c|c|c|}
\hline \multicolumn{2}{|c|}{$\begin{array}{l}\text { Infection with a } \\
\text { single HPV type } \\
n(\%)\end{array}$} & \multicolumn{2}{|c|}{$\begin{array}{l}\text { Infection with } \\
\text { two HPV types } \\
n(\%)\end{array}$} & \multicolumn{2}{|c|}{$\begin{array}{l}\text { Infection with } \\
\text { three HPV types } \\
n(\%)\end{array}$} \\
\hline 16 & $44(28.2)$ & $1 a+57 c$ & $2(1.3)$ & $1 a+2+4$ & $1(0.64)$ \\
\hline $27 b$ & $23(14.7)$ & $6+57 c$ & $2(1.3)$ & $1 a+2+16$ & $1(0.64)$ \\
\hline $57 c$ & $22(14.1)$ & $16+57 c$ & $2(1.3)$ & $1 a+57 c+65$ & $1(0.64)$ \\
\hline 6 & $16(10.3)$ & $1 a+27 b$ & $1(0.64)$ & $9+27 b+65$ & $1(0.64)$ \\
\hline 2 & $15(9.6)$ & $1 a+33$ & $1(0.64)$ & & \\
\hline 65 & $7(4.5)$ & $1 a+16$ & $1(0.64)$ & & \\
\hline $1 a$ & $2(1.3)$ & $2+27 b$ & $1(0.64)$ & & \\
\hline 18 & $2(1.3)$ & $6+2$ & $1(0.64)$ & & \\
\hline $57 b$ & $2(1.3)$ & $6+27 b$ & $1(0.64)$ & & \\
\hline 7 & $1(0.64)$ & $6+65$ & $1(0.64)$ & & \\
\hline 9 & $1(0.64)$ & $16+27 b$ & $1(0.64)$ & & \\
\hline 27 & $1(0.64)$ & $16+2$ & $1(0.64)$ & & \\
\hline 38 & $1(0.64)$ & & & & \\
\hline 81 & $1(0.64)$ & & & & \\
\hline
\end{tabular}

Data are numbers of patients (\%). Listed are the most prevalent HPV types, other types occurred in multiple infection including HPV 4 and HPV 33 included in the study. Anogenital warts included warts taken from penis, pubic area, anus, perianal area and vulva. The mean of their ages was 35.36 years, Standard Deviation (SD) was 9.59, median was 33 years, and range was $16-56$ years. The mean of male patient ages was 34 and the mean of female ages was 42 .

Data revealed that the majority of patients $(98.1 \%)$ had more than one wart for a duration of more than one month, and of size between one and two centimeters. Of note, $75.6 \%$ of the patient partners had no anogenital warts (Table 1).

The analysis of the sequencing results showed that there were 16 different HPV genotypes detected in this

Table 3 Association of demographic and warts characteristics with oncogenic HPV detection $(N=156)$

\begin{tabular}{|c|c|c|c|}
\hline Characteristic & $\begin{array}{l}\text { Oncogenic } \\
\text { HPV } \\
n(\%)\end{array}$ & $\begin{array}{l}\text { Non-Oncogenic } \\
\text { HPV } \\
n(\%)\end{array}$ & P. Value \\
\hline Gender & & & $0.462^{3}$ \\
\hline Male & 43 (33.3) & $86(66.7)$ & \\
\hline Female & $11(40.7)$ & $16(59.3)$ & \\
\hline Nationality & & & $0.219^{3}$ \\
\hline Kuwaiti & $31(39.2)$ & $48(60.8)$ & \\
\hline Non-Kuwaiti & $23(29.9)$ & $54(70.1)$ & \\
\hline Number of Warts & & & $0.614^{2}$ \\
\hline One & $1(33.3)$ & $2(66.7)$ & \\
\hline Two - Four & $34(38.2)$ & $55(61.8)$ & \\
\hline At least Five & $19(29.7)$ & $45(70.3)$ & \\
\hline $\begin{array}{l}\text { Duration of presence of } \\
\text { each Wart }\end{array}$ & & & $0.162^{3}$ \\
\hline Less than one month & $6(18.2)$ & $27(81.8)$ & \\
\hline One - six months & $31(38.8)$ & $49(61.3)$ & \\
\hline Seven - Twelve months & $12(41.4)$ & 17 (58.6) & \\
\hline More than 12 months & $5(35.7)$ & $9(64.3)$ & \\
\hline Size of each Wart & & & $0.047^{4}$ \\
\hline Less than one $\mathrm{Cm}^{1}$ & $9(25.0)$ & $27(75.0)$ & \\
\hline One $\mathrm{Cm}$ & $9(24.3)$ & $28(75.7)$ & \\
\hline One - two Cm & $31(44.3)$ & $39(55.7)$ & \\
\hline More than two $\mathrm{Cm}$ & $5(38.5)$ & $8(61.5)$ & \\
\hline $\begin{array}{l}\text { Wart subject to prior } \\
\text { treatment }\end{array}$ & & & $0.060^{3}$ \\
\hline No & $26(28.6)$ & $65(71.4)$ & \\
\hline Yes & $28(43.1)$ & $37(56.9)$ & \\
\hline Partner has Warts & & & $0.469^{3}$ \\
\hline No & $39(33.1)$ & 79 (66.9) & \\
\hline Yes & $15(39.5)$ & $23(60.5)$ & \\
\hline
\end{tabular}

Data are numbers of patients (\%). ${ }^{1:}$ Centimeter. Oncogenic HPV if it is positive in one of HPV types: $16,18,33$ and 38. Non-oncogenic HPV if it is positive in one of HPV types: $1 \mathrm{a}, 2,6,7,9,27,27 \mathrm{~b}, 57 \mathrm{~b}, 57 \mathrm{c}, 65$ and $81 .{ }^{2}$ Fisher exact test, ${ }^{3}$ Pearson Chi square test, ${ }^{4}$ Chi square test for trend 
study, including HPV genotype 1a, 2, 4, 6, 7, 9, 16, 18, $27,27 \mathrm{~b}, 33,38,57 \mathrm{~b}, 57 \mathrm{c}, 65$ and 81 . Table 2 presents the prevalence of HPV genotypes according to whether the patient was infected with single, double, or triple HPV types. The prevalence of oncogenic HPV genotypes (HPV 16, 18, 33 and 38) was 54/156 (34.62\%), whereas that of LR HPV genotype (HPV 6 and 81) was 22/156 (14.1\%) and common warts viruses (1a, 2, 7, 27b, 27, 57b, 57c, 65) was 50.6\%. HPV infection with a single type, two types, and three types was found in 88.4, 9, and $2.6 \%$ of patients, respectively.

The association between oncogenic HPV genotypes (HPV 16, 18, 33 and 38) with demographic data and warts characteristics is shown in Table 3 . The mean age of patients with oncogenic viruses was 36 years, SD of 9.8 , median, 33 years and range, $18-56$ years. The mean age of patients with non-oncogenic viruses was 35 years,
SD of 7.9, median, 33 years, and range, $16-56$ years, and the mean difference in age was statistically significant $(\mathrm{PV}=0.006)$. The multiple logistic regression model (Table 4) indicated that age, gender, nationality, number of warts, size of each wart and if partner has warts were not significantly associated with oncogenic HPV infection. However, the adjusted Odds Ratio (OR) for detecting oncogenic HPV type in a wart of one to six months duration, was three times higher than that of a wart with less than one month duration.

\section{Discussion}

This study aimed to investigate the relationship between the type specific distribution of HPV genotypes and clinical characteristics of patients with HPV-infected anogenital warts. It is among few that correlate clinical presentation of warts and demographic data of patients

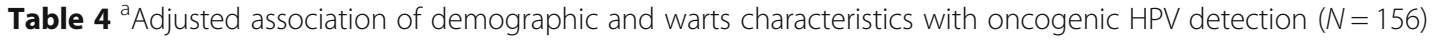

\begin{tabular}{|c|c|c|c|c|}
\hline Covariate & $\begin{array}{l}\text { Crude } \\
\text { OR }(95 \% \text { Cl) }\end{array}$ & $P$-Value & $\begin{array}{l}\text { Adjusted } \\
\text { OR ( } 95 \% \text { Cl) }\end{array}$ & $P$-Value \\
\hline Age (years) & $1.01(0.98,1.05)$ & 0.467 & $1.02(0.98,1.06)$ & 0.447 \\
\hline \multicolumn{5}{|l|}{ Gender } \\
\hline Female & 1 (ref) & & 1 (ref) & \\
\hline Male & $0.73(0.31,1.70)$ & 0.463 & $0.76(0.24,2.38)$ & 0.639 \\
\hline \multicolumn{5}{|l|}{ Nationality } \\
\hline Non-Kuwaiti & 1 (ref) & & 1 (ref) & \\
\hline Kuwaiti & $1.52(0.78,2.95)$ & 0.220 & $1.01(0.42,2.45)$ & 0.984 \\
\hline Number of Warts & & 0.552 & & 0.221 \\
\hline One & 1 (ref) & & 1 (ref) & \\
\hline Two-Four & $1.24(0.11,14.16)$ & 0.865 & $2.32(0.15,34.95)$ & 0.544 \\
\hline At least five & $0.84(0.07,9.88)$ & 0.893 & $1.13(0.07,17.47)$ & 0.929 \\
\hline Duration of Wart (months) & & 0.184 & & 0.114 \\
\hline Less than one & 1 (ref) & & 1 (ref) & \\
\hline One - Six & $2.85(1.06,7.68)$ & 0.039 & $3.06(1.03,9.09)$ & 0.045 \\
\hline Seven - Twelve & $3.18(1.01,10.06)$ & 0.049 & $1.12(0.25,5.05)$ & 0.879 \\
\hline More than Twelve & $2.50(0.61,10.20)$ & 0.202 & $1.70(0.32,9.09)$ & 0.535 \\
\hline Size of each Wart $(\mathrm{Cm})^{\mathrm{b}}$ & & 0.109 & & 0.258 \\
\hline$<1$ & 1 (ref) & & 1 (ref) & \\
\hline 1 & $0.964(0.333,2.80)$ & 0.947 & $0.61(0.19,2.03)$ & 0.424 \\
\hline Between 1 and 2 & $2.39(0.98,5.81)$ & 0.056 & $1.66(0.57,4.86)$ & 0.353 \\
\hline$>2$ & $1.88(0.49,7.22)$ & 0.361 & $1.43(0.31,6.74)$ & 0.649 \\
\hline \multicolumn{5}{|c|}{ Wart subject to prior treatment } \\
\hline No & 1 (ref) & & 1 (ref) & \\
\hline Yes & $1.89(0.97,3.69)$ & 0.062 & $1.63(0.72,3.70)$ & 0.246 \\
\hline \multicolumn{5}{|l|}{ Partner has Warts } \\
\hline No & 1 (ref) & & 1 (ref) & \\
\hline Yes & $1.32(0.62,2.81)$ & 0.470 & $1.31(0.53,3.22)$ & 0.563 \\
\hline
\end{tabular}

${ }^{\mathrm{a}}$ The binary outcome is the results of HPV sequencing being oncogenic genotype ( $1=$ Yes, $0=$ No), Oncogenic HPV genotypes include: $16,18,33$ and 38 
with HPV infection. Unexpectedly, for single type infection, HPV 16 was the most common HPV genotype detected in anogenital warts (28.2\%), while HPV 6 prevalence was only $10.3 \%$. As commonly known, LR HPV 6 and HPV 11 are mostly encountered for anogenital warts and HR HPV 16 is always encountered in lower prevalence [5, 7-9].

The authors were surprised to find that HPV 11 was not detected in this cohort. This could be due to the low prevalence of this HPV genotype in anogenital warts. This study is the first of its kind in the Arabian Gulf region further studies are needed in Kuwait and in the region to confirm the outcome of this study. Around $83 \%$ of patients in this study were men, due to the fact that, in Kuwait, most women with external genital warts are referred to a gyneacology clinic. The findings of this study show that the mean age of patients infected with HPV (35.3 years) or with HR HPV genotypes ( 36.2 years) was higher than what is documented worldwide [15].

HPV vaccines were first developed to reduce the number of HPV related cancers and precancerous changes in women. For long-term benefit, it was shown that HPV vaccination reduced the number of HPV related diseases in women, including condyloma acuminata of the vagina, vulva and, of course, perianal areas and cervical intraepithelial neoplasia; and, in men, including anogenital condyloma acuminata and penile intraepithelial neoplasia [10, 24]. Gardasil nonavalent HPV vaccine was designed to target HPV genotypes 6, 11, 16, 18, 31, 33, 45, 52 and 58. According to the outcome of this study, about $50 \%$ of anogenital warts are infected with HPV genotypes 6, 16, 18 and 33, and the use of nonavalent HPV vaccine for both sexes would result in the reduction of about $50 \%$ of anogenital warts in the studied population which will help in reducing the morbidity of having anogenital warts, and the cost of treatment.

This study shows that the risk of having a genital wart infected with HPV types 16, 18, 33 or 38 increases in a wart of one to six months duration. This could be due to the fact that HR HPV genotypes, especially HPV 16, have longer time to clearance than other genotypes [21]. Other studies linked the development of genital warts and HPV infection to factors related to patients' sexual behavior, including number of partners [22], men having sex with men [27] and having sex at a young age [11]. Other studies showed that patients who smoke cigarette [25] and marijuana [19] were at high risk of having HPV infection.

\section{Conclusions}

This study shows that oncogenic HPV types are detected in around $35 \%$ of patients with genital warts, and are prevalent in warts of one to six months duration.

\section{Abbreviations}

bp: Base pair; Cm: Centimeter; HPV: Human papillomavirus; HR: High-risk; IR: Intermediate-risk; LR: Low-risk; OR: Odds Ratio; ORF: Open reading frame; PBS: Phosphate buffered saline; SD: Standard Deviation; STI: Sexually transmitted infections; $\mu$ : Microliters

\section{Acknowledgements}

The authors are grateful to staff in the Research Core Facility, Project No. SRUL 02/13 for their help and assistance.

\section{Funding}

This work was funded by Kuwait University through the Research Administration (Research Project No. NM 01/12). The funder had no role in study design, data collection, analysis, decision to publish or preparation of manuscript.

\section{Availability of data and materials}

The datasets used and/or analyzed during the current study are available from the corresponding author on reasonable request.

\section{Authors' contributions}

RA is responsible for the design of the study, writing the grant, monitoring virology work, analysis of results and writing manuscript. WC is responsible for virology work. NM is responsible for collection of samples. AA is responsible for statistical analysis. All authors read and approved the final manuscript.

\section{Ethics approval and consent to participate}

An ethical approval was obtained from the Health Science Center Ethical Committee, Kuwait University (Number: VDR/EC/2310) and Ministry of Health. Each patient was interviewed and consented to enter the study. Patients were asked to sign a consent form after a verbal explanation from the physician soliciting their participation. All study procedures were performed in compliance with the ethical standards of the revised Declaration of Helsinki of 2008 .

\section{Consent for publication}

Not applicable.

\section{Competing interests}

The authors declare that they have no competing interests.

\section{Publisher's Note}

Springer Nature remains neutral with regard to jurisdictional claims in published maps and institutional affiliations.

\section{Author details}

${ }^{1}$ Department of Medical Laboratory Sciences, Faculty of Allied Health Sciences, Kuwait University, P.O. Box 31470, 90805 Sulaibikhat, Kuwait. ${ }^{2}$ Dermatology Unit, Department of Medicine, Faculty of Medicine, Kuwait University, Kuwait City, Kuwait. ${ }^{3}$ Department of Community Medicine and Behavioral Sciences, Faculty of Medicine, Kuwait University, Kuwait City, Kuwait. ${ }^{4}$ Virology Unit, Department of Microbiology, Faculty of Medicine, Kuwait University, Kuwait City, Kuwait.

Received: 2 February 2019 Accepted: 18 April 2019

Published online: 02 May 2019

References

1. Al-Awadhi R, Chehadeh W, Jaragh M, Al-Shaheen A, Sharma P, Kapila K. Distribution of human papillomavirus among women with abnormal cervical cytology in Kuwait. Diag Cytopathol. 2013;41:107-14. https://doi. org/10.1002/dc.21778.

2. Al-Awadhi R, Chehadeh W, Kapila K. Prevalence of human papillomavirus among women with normal cervical cytology in Kuwait. J Med Virol. 2011; 83:453-60. https://doi.org/10.1002/jmv.21981.

3. Al-Fouzan A, Al- Mutairi N. Overview of incidence of sexually transmitted diseases in Kuwait. Clin Dermatol. 2004;22:509-12. https://doi.org/10.1016/j. clindermatol.2004.07.002

4. Al-Mutairi N, Joshi A, Nour-Eldin O, Sharma A, El-Adawy E, Rijhwani M. Clinical patterns of sexually transmitted diseases, associated 
sociodemographic characteristics, and sexual practices in the Farwaniya region of Kuwait. International J Dermatol. 2007:46:594-9. https://doi.org/10. 1111/j.1365-4632.2007.02843.x.

5. Anic GM, Lee JH, Stockwell H, Rollison DE, Wu Y, Papenfuss MR, et al. Incidence and human papillomavirus (HPV) type distribution of genital warts in a multinational cohort of men: the HPV in men study. J Infect Dis. 2011;204:1886-92. https://doi.org/10.1093/infdis/jir652.

6. Atula S, Grenman R, Kujari H, Syrjänen S. Detection of human papillomavirus (HPV) in laryngeal carcinoma cell lines provides evidence for a heterogeneic cell population. Eur J Cancer. 1999;35:825-32.

7. Aubin F, Prétet $J$, Jacquard AC, Saunier M, Carcopino X, Jaroud F, et al. EDiTH Study group. Human papillomavirus genotype distribution in external acuminata condylomata: a large French National Study (EDiTH IV). Clin Infect Dis. 2008;47:610-5. https://doi.org/10.1086/590560.

8. Chan PK, Luk AC, Luk TN, Lee KF, Cheung JL, Ho KM, et al. Distribution of human papillomavirus types in anogenital warts of men. J Clin Virol. 2009;44:111-4. https://doi.org/10.1016/j.jcv.

9. Chang L, Ci P, Shi J, Zhai K, Feng X, Colombara D, et al. Distribution of genital wart human papillomavirus genotypes in China: a multi-center study. J Med Virol. 2013;85:1765-74. https://doi.org/10.1002/jmv.23646.

10. Chow EP, Read TR, Wigan R, Donovan B, Chen MY, Bradshaw CS, et al. Ongoing decline in genital warts among young heterosexuals 7 years after the Australian human papillomavirus (HPV) vaccination programme. Sex Transm Infect. 2015;9:214-9. https://doi.org/10.1136/sextrans-2014-051813.

11. Daugherty M, Byler T. Genital wart and human papillomavirus prevalence in men in the United States from penile swabs: results from National Health and nutrition examination surveys. Sex Transm Dis. 2018;45:412-6. https:// doi.org/10.1097/OLQ.0000000000000761.

12. De Koning M, Schegget J, Eekhof J, Kamp M, Kleter B, Gussekloo J, et al. Evaluation of a novel broad-Spectrum PCR-multiplex genotyping assay for identification of cutaneous wart-associated human papillomavirus types. J Clin Microbiol. 2010;48:1706-11. https://doi.org/10.1128/JCM.02122-09.

13. Dinh TH, Sternberg M, Dunne EF, Markowitz LE. Genital warts among 18- to 59-year-olds in the United States, national health and nutrition examination survey, 1999-2004. Sex Transm Dis. 2008;35:357-60. https://doi.org/10.1097/ OLQ.0b013e3181632d61.

14. Giuliano AR, Anic G, Nyitray AG. Epidemiology and pathology of HPV disease in males. Gynecol Oncol. 2010;117(2 Suppl):S15-9. https://doi.org/10. 1016/j.ygyno.2010.01.026

15. Giuliano AR, Tortolero-Luna G, Ferrer E, Burchell AN, de Sanjose S, Kjaer SK, et al. Epidemiology of human papillomavirus infection in men, cancers other than cervical and benign conditions. Vaccine. 2008;26 (S10:K17-28. https://doi.org/10.1016/j.vaccine.2008.06.021.

16. Gravitt PE, Peyton CL, Apple RJ, Wheeler M. Genotyping of 27 human papillomavirus types by using L1 consensus PCR products by a single hybridization reverse line blot detection method. J Clin Microbiol. 1998;36: 3020-7

17. Gupta G, Glueck R, Patel PR. HPV vaccines: Global perspectives. Hum Vaccin Immunother. 2017;13:1-4. https://doi.org/10.1080/21645515.2017.1289301.

18. Harwood CA, Spink PJ, Surentheran T, Leigh IM, De Villiers LM, McGregor $J M$, et al. Degenerate and nested PCR: a highly sensitive and specific method for detection of human papillomavirus infection in cutaneous warts. J Clin Microbiol. 1999:37:3545-55.

19. Kaderli R, Schnuriger B, Brugger LE. The impact of smoking on HPV infection and the development of anogenital warts. Int J Color Dis. 2014;29:899-908. https://doi.org/10.1007/s00384-014-1922-y.

20. Lum A, Le Marchand L. A simple mouthwash method for obtaining genomic DNA in molecular epidemiological studies. Cancer Epidemiol Biomark Prev. 1998;7:719-24.

21. Moreira ED Jr, Giuliano AR, Palefsky J, Flores CA, Goldstone S, Ferris D, Hillman RJ, Moi H, Stoler MH, Marshall B, Vuocolo S, Guris D, Haupt RM. Incidence, clearance, and disease progression of genital human papillomavirus infection in heterosexual men. J Infect Dis. 2014;210:192-9. https://doi.org/10.1093/infdis/jiu077.

22. Nielson CM, Harris RB, Dunne EF, Abrahamsen M, Papenfuss MR, Flores R, et al. Risk factors for anogenital human papillomavirus infection in men. J Infect Dis. 2007;196:1137-45. https://doi.org/10.1086/521632.

23. Olesen TB, Sand FL, Rasmussen CL, Albieri V, Toft BG, Norrild B, Munk C, Kjær SK. Prevalence of human papillomavirus DNA and p16INK4a in penile cancer and penile intraepithelial neoplasia: a systematic review and meta- analysis. Lancet Oncol. 2019;20:145-58. https://doi.org/10.1016/S14702045(18)30682-X.

24. Read TR, Hocking JS, Chen MY, Donovan B, Bradshaw CS, Fairley CK. The near disappearance of genital warts in young women 4 years after commencing a national human papillomavirus (HPV) vaccination programme. Sex Transm Infect. 2011;87:544-7. https://doi.org/10.1136/ sextrans-2011-050234.

25. Schabath MB, Villa LL, Lazcano-Ponce E, Salmerón J, Quiterio M, Giuliano AR, Study HIM. Smoking and human papillomavirus (HPV) infection in the HPVinMen (HIM) study. Cancer Epidemiol Biomark Prev. 2012;21:102-10. https://doi.org/10.1158/1055-9965.EPI-11-0591.

26. Trottier $H$, Burchell AN. Epidemiology of mucosal human papillomavirus infection and associated diseases. Public Health Genomics. 2009;12:291-307. https://doi.org/10.1159/000214920.

27. Vajdic CM, van Leeuwen MT, Jin F, Prestage G, Medley G, Hillman RJ, et al. Anal human papillomavirus genotype diversity and co-infection in a community-based sample of homosexual men. Sex Transm Infect. 2009;85:330-5. https://doi.org/10.1136/sti.2008.034744.

28. Wiley DJ, Douglas J, Beutner K, Cox T, Fife K, Moscicki AB, et al. External genital warts: diagnosis, treatment, and prevention. Clin Infect Dis. 2002;35(Suppl 2):S210-24. https://doi.org/10.1086/342109.

\section{Ready to submit your research? Choose BMC and benefit from:}

- fast, convenient online submission

- thorough peer review by experienced researchers in your field

- rapid publication on acceptance

- support for research data, including large and complex data types

- gold Open Access which fosters wider collaboration and increased citations

- maximum visibility for your research: over $100 \mathrm{M}$ website views per year

At BMC, research is always in progress.

Learn more biomedcentral.com/submissions 